\title{
VITAMIN D SEBAGAI TERAPI POTENSIAL ANAK GIZI BURUK
}

\author{
Lisa Dwi Aryani*, Muhammad Aldy Riyandry \\ Fakultas Kedokteran, Universitas Lampung, J1. Prof. Dr. Ir. Sumantri Brojonegoro No.1, Gedong Meneng, Kec. \\ Rajabasa, Kota Bandar Lampung, Lampung, Indonesia 35145 \\ * lisadwiaryani1@gmail.com (+6282371622710)
}

\begin{abstract}
ABSTRAK
Masalah malnutrisi (gizi buruk) masih menjadi isu kesehatan global. Gizi buruk merupakan penyebab kematian tertinggi anak di negara berkembang. Malnutrisi adalah keadaan kekurangan energi dan protein berat akibat ketidakseimbangan antara ambilan makanan dengan kebutuhan gizi. Keadaan malnutrisi energi-protein sering dikaitkan dengan temuan kasus defisiensi vitamin D. Berdasarkan studi epidemiologi $>50 \%$ anak malnutrisi berat juga mengalami defisiensi vitamin D. Pengoreksian melalui diet terapeutik sebagai standar pengobatan hanya mengandung vitamin D dalam jumlah sedang sehingga tidak cukup adekuat untuk mencukupi kebutuhan anak. Pemberian tambahan vitamin D3 dosis tinggi sebanyak $200.000 \mathrm{IU}$ (5 mg) diduga mampu mengoreksi keadaan gizi buruk dengan meningkatkan berat badan dan nilai $z$-score anak. Literature review ini bertujuan untuk menjelaskan pengaruh pemberian vitamin $\mathrm{D}$ dalam memperbaiki tampilan klinis anak gizi buruk. Metode yang digunakan dalam artikel ini adalah penelusuran artikel melalui database NCBI dan Google Scholar. Tahun penerbitan sumber pustaka adalah dari tahun 2004 hingga 2019 dengan 29 sumber pustaka. Tema dalam artikel yang dikumpulkan yaitu terkait gambaran pengaruh pemberian vitamin D dalam meningkatkan berat badananak gizi buruk. Hasil dari sintesa 24 artikel yang telah ditemukan terdapat pengaruh pemberian vitamin D (cholecalciferol) terhadap kenaikan berat badan sebagai hasil kumulatif lemak di jaringan adiposa sehingga cukup potensial sebagai terapi gizi buruk.
\end{abstract}

Kata kunci: Vitamin D, gizi buruk, berat badan, cholecalciferol

\section{VITAMIN D AS POTENTIAL THERAPY FOR MALNUTRITION CHILD}

\begin{abstract}
Malnutrition (malnutrition) is still a global health problem. Malnutrition is the highest cause of deaths children in developing countries. Malnutrition is the impact of lack of energy and protein due to an imbalance between food intake and nutritional needs. The symptoms are marasmus, kwashiorkor or marasmik-kwashiorkor. Energy-protein malnutrition is often related to the case finding of vitamin $D$ deficiency, which is caused by epidemiological studies $>50 \%$ of severely malnourished children also have vitamin D deficiency. Correcting malnutrition with a therapeutic diet as a standard is sufficient to meet the child's needs. An additional 200,000 IU (5 mg) of high-dose vitamin D3 supplements can replace malnutrition by increasing the child's weight and z-score. This review summarizes the role of vitamin $D$ as a potential therapy in improving infant health and well-being and malnutrition. The method taken by the article was made using the literature review method, involving 29 books, national or international journals. The results of a review of 24 articles that show the difference between vitamin $D$ (cholecalciferol) and weight gain as a result of cumulative fat in adipose tissue through increased intracellular calcium, is quite potentially used as a supplementary therapy for child nutrition.
\end{abstract}

Keywords: vitamin D, malnutrition, weight, cholecalciferol 


\section{PENDAHULUAN}

Nutrisi memiliki peran penting dalam pembentukan sumber daya manusia (SDM) berkualitas, sehat, cerdas dan produktif (Lelijveld et al., 2016).Gangguan pemenuhan nutrisi (malnutrisi) secara kronis merupakan faktor risiko tinggi gizi buruk. Gizi buruk terjadi akibat malabsorpsi atau kegagalan metabolik.Gejala klinis gizi buruk diketahui melalui indikator pengukuran berat badan (BB), tinggi badan (TB) dan lingkar lengan (LILA)jauh di bawah rata-rata.Gizi buruk dapat berefek jangka panjang terhadap perkembangan fisik, mental dan kualitas kehidupan anak (Saboya et al., 2011).

Berdasarkan data World Organizations of HealthWHO tahun 2013, lebih dari 50\% kematian anak di negara berkembang disebabkan kondisi gizi buruk (United Nations, 2013).Menurut data Profil Kesehatan Indonesia tahun 2013, kejadian anak gizi buruk mencapai $4,9 \%$ pada tahun 2010 dan meningkat sebanyak 5,7\% pada tahun 2013 (Kemenkes, 2015). Peningkatan kejadian gizi buruk di Indonesia terus berkembang pesat sampai tahun 2018 dengan prevalensi $17,7 \%$. Target Sustainable Development Goals (SDGs) (2019) adalah tidak ada lagi kasus gizi buruk di Indonesia pada tahun 2030. Hal ini menunjukkan bahwa kasus gizi burukmemiliki urgensi yang tinggi untuk ditekan jumlah kejadiannya (Kemenkes 2019).

Upaya peningkatan kesehatan anak gizi buruk dilakukan dengan pemberian makanan terapeutik siap saji (ready to use therapeutic food $=$ RUTF). RUTF berupa susu formula-75 (F75) dan formula-100 (F100) merupakan makanan dengan desain kaya mikronutrien dan padat energi. Pemberian RUTF terbagi menjadi fase stabilisasi,transisi dan rehabilitasi. Fokus pemberian RUTF fase stabilisasi adalah pemenuhan metabolisme basal. Pemberian RUTF fase transisi dan rehabilitasi cenderung sebagai sarana tumbuh kejar
(Kemenkes, 2011). Upaya peningkatan respons terhadap RUTF menjadi hal yang saat ini dipertimbangkan oleh Badan Kesehatan Dunia (WHO), termasuk pemberian terapi antibiotik maupun vitamin dosis tinggi (WHO, 2013).

Pemberian vitamin Ddosis tinggi diduga mampu meningkatkan berat badan dan perkembangan tubuh anak gizi buruk (Leblanc et al., 2012). Kandungan vitamin D pada RUTF hanya berjumlah sedang yaitu sekitar $600 \mathrm{IU} /$ sachet. Asupan vitamin D yang diterima mungkin tidak cukup untuk meningkatkan konsentrasi25hidroksivitamin D [25 (OH) D] anak gizi buruk. Sebab, berdasarkan studi epidemiologis, $>50 \%$ anak gizi buruk juga mengalami defisiensi vitamin D berat.Anak gizi buruk berisiko tinggi terkena penyakit infeksi dan menimbulkan respon inflamasi sistemik. Respon inflamasi yang ditimbulkan dapat merusak metabolisme vitamin $\mathrm{D}$ sehigga defisiensi vitamin $\mathrm{D}$ dapat bertambah berat(Gordon et al., 2008; Jones et al., 2018; Raghuramulu \& Reddy, 1980).Berdasarkan kondisi tersebut, maka pemberian vitamin $\mathrm{D}$ sebagai terapi tambahan memiliki urgensi yang tinggi untuk diteliti manfaatnya dalam mengobati anak gizi buruk.

Literature review ini bertujuan untuk menjelaskan pengaruh pemberian vitamin $\mathrm{D}$ dalam memperbaiki tampilan klinis anak gizi buruk. Penelitian ini dapatmembuka penemuan baru dalam pemberian terapi yang lebih baik pada anak gizi buruk. Jenis penelitian ini adalah tinjauan pustakadimana hasil dan pembahasan didasarkanpada sumber ilmiah yang valid dan akurat.

\section{METODE}

Metode yang digunakan dalam penulisanartikel ini adalah literature review. Sumberpustaka yang digunakan dalam artikel inimelibatkan 29 pustaka baik yang berasal daribuku, jurnal nasional atau internasionalmaupun website. Penelusuran 
sumberpustaka dalam artikel ini melalui databaseNCBI dan Google Scholar dengan kata kunciVitamin $D$, Acute Severe Malnutrition, Therapy, Weight Gain, Calcium, Lipogenesis, Z-Score. Pemilihan artikel sumber pustaka dilakukandengan melakukan peninjauan pada judul danabstrak yaitu yang membahas tentang pengaruh pemberian vitamin $\mathrm{D}$ dalam membantu meningkatkan berat badan termasuk anak dengan status gizi buruk. Tahun penerbitan sumber pustakayang digunakan dalam penulisan artikel iniadalah dari tahun 2005 hingga tahun 2019.

\section{HASIL}

Menurut penelitian Cann, et.al (2007) melakukan sebuah uji coba acak dengan 36.282 wanita pascamenopause, berusia 50 hingga 79 tahun. Wanita tersebut secara acak diberikan dosis 1000 mg kalsium dan ditambah 400 IU cholecalciferol (vitamin D) atau plasebo setiap hari. Hasil dari peneltian menunjukkan bahwa pemberian suplemen kalsium dan kolekalsiferol memiliki efek kecil pada pencegahan penambahan berat badan, yang diamati terutama pada wanita yang melaporkan asupan kalsium yang tidak memadai. Hal ini terjadi sebab vitamin D (kolekalsiferol) berperan dalam regulasi metabolisme lemak seperti lipogenesis, lipolisis, adipogenesis dan transkripsi-en adiposit. Sehingga, pemberian vitamin larut lemak seperti vitamin $\mathrm{D}$ diduga berperan dalam peningkatan berat badan.

Penelitian Saleem et al., 2018 menunjukkan bahwa pemberian vitamin $\mathrm{D}$ dosis tinggi dapat meningkatkan berat badan anak gizi buruk. Penelitian dilakukan dengan memberikan tambahan vitamin dosis tinggi, yaitu 200.000 IU (5 mg) yang terbagi menjadi dua dosis dan dikonsumsi secara oral maupuan parenteral. Hasil dari penelitiannya, ditemukan kenaikan berat badan anak gizi buruk secara signifikan dengan rata-rata berat badan $0,26 \mathrm{~kg}$ dibandingkan kelompok kontrol. Vitamin D dosis tinggi juga menunjukkan pengaruh positif bagi anak-anak yang memiliki gangguan perkembangan motorik, bahasa dan gangguan lainnya, termasuk kesulitan belajar berjalan dan berbicara.

\section{PEMBAHASAN \\ Status Gizi Anak}

Status gizi adalah ukuran kondisi tubuh yang dilihat dari konsumsi makanan dan penggunaan zat gizi. Status gizi sangat ditentukan oleh ketersediaan zat gizi di tingkat sel yang dipengaruhi oleh kebutuhan, penyerapan, dan penggunaan zat-zat tersebut. Penilaian status gizi dapat dilihat secara langsung dan tidak langsung.Penilaian secara langsung antara lain dengan antropometri, klinis, biokimia, dan biofisik. Penilaian status gizi tidak langsung meliputi survei konsumsi makanan, statistik vital dan faktor ekologi. Pemantauan status gizi dengan antropometri dianggap paling baik. Pengukuran status gizi dengan antropometri berhubungan dengan pengukuran dimensi tubuh dan komposisi tubuh dari berbagai tingkat umur dan gizi. Indikator penilaian status gizi meliputi berat badan (BB), tinggi badan (TB/PB) dan lingkar lengan atas (LILA) (Kemenkes, 2011).

Penilaian status gizi anak disarankan WHO menggunakan standar deviasi atau Z-score. Indikator penilaian status gizi anak yang bersifat umumberupa berat badan menurut umur $(\mathrm{BB} / \mathrm{U})$, bersifat kronisberupa tinggi badan menurut umur (TB/U) dan bersifatakut berupa berat badan per tinggi badan (BB/TB). Indeks pengukuran antropometri berat badan merupakan parameter yang memberikan gambaran massa tubuh. Berat badan (BB) merupakan indikator yang sangat sensitif terhadap perubahan-perubahan yang mendadak seperti menderita penyakit, penurunan nafsu makan atau jumlah makanan yang dikonsumsi (Hidayat, 2001). Tinggi badan (TB) merupakan ukuran antropometri yang menggambarkan pertumbuhan skeletal. Pertumbuhan tinggi badan relatif kurang sensitif bila dibandingkan berat badan 
sebab tinggi badan merepresentasikan konsumsi protein masa lalu. Ukuran berat badan, tinggi badan dan umur memiliki hubungan yang linier (Supariasa, 2012).

Menurut WHO, status gizi anak berdasarkan standar deviasi dibagi menjadi tiga kategori, yaitu perhitungan berat badan menurut tinggi atau panjang badan (BB/TBPB) -2 standar deviasi (SD) menunjukkan bahwa anak berada pada batas terendah kisaran normal (-2 sampai +2 SD), >2 SD anak tergolong gemuk dan <-3 SD menunjukkan anak sangat kurus (severe wasting). Anak-anak gizi buruk memiliki nilai $z$-scores <-3 SD (Lestari, Margawati, $\&$ Rahfiludin, 2014).

\section{Gizi Buruk}

Gizi Buruk adalah suatu keadaan kekurangan energi dan protein berat dengan gejala klinis kwashiorkor, marasmus atau marasmik-kwashiorkor. Marasmus memiliki ciri anak sangat kurus, wajah tua, cengeng, kulit keriput dan perut cekung. Kwashiokor memiliki ciri adanya edema di seluruh tubuh terutama bagian ekstremitas, wajah sembab, mata sayu, rambut tipis kemerahan seperti jagung dan otot yang mengecil. Sedangkan marasmikkwashiorkor adalah gabungan beberapa tanda marasmus dan kwashiokor dengan gejala edema yang tidak menonjol (Kemenkes, 2015).

\section{Metabolisme Vitamin D}

Tubuh kita memperoleh vitamin $\mathrm{D}$ dengan 2 cara berbeda, yaitu bersumber dari sintesis langsung di epidermis kulit setelah paparan sinar ultraviolet dan bersumber dari asupan makanan. Terdapat lebih dari 50 jenis metabolit vitamin $\mathrm{D}$ dengan jenis utamanya adalah vitamin D3 (cholecalciferol) dan D2 (ergocalciferol). Kedua jenis vitamin D ini menjalani hidroksilasi di hati untuk disimpan menjadi 25-hidroksi vitamin D $(25[\mathrm{OH}]-\mathrm{D}$, calcidiol, atau calcifediol). Selanjutnya, hidroksilasi calsidiol akan menyintesis metabolit aktifnya, 1,25-dihidroksivitamin
D (1,25 [OH] -D) (calsitriol), di ginjal. Calsitriol bertanggung jawab pada organ intraskeletal untuk meningkatkan penyerapan kalsium, resorpsi tulang, dan mengurangi ekskresi kalsium dan fosfat pada tulang. Sintesis kalsitriol dimediasi oleh Parathyroid Hormone (PTH), fosfat serum, dan hormon pertumbuhan. Selain itu, vitamin D juga bertanggung jawab pada organ ekstraskeletal. Reseptor vitamin D di usus kecil, usus besar dan osteoblast dapat mengaktivasi limfosit $\mathrm{T}$ dan $\mathrm{B}$, sel islet beta, dan organ utama (otak, jantung, kulit, gonad, prostat, payudara, dan sel mononuklear) untuk menimbulkan efek imunologis (Herrmann, Farrell, Pusceddu, Fabregat-Cabello, \& Cavalier, 2017; Lee, So, \& Thackray, 2013)

\section{Mekanisme Vitamin D Membantu Anak Gizi Buruk}

Anak-anak yang mengalami gizi buruk sering dikaitkan dengan defisiensi vitamin $D$ berat. Sebab, vitamin D dapat memengaruhi regulasi kalsium. Berdasarkan studi epidemiologis, > 50\% anak mengalami defisiensi vitamin D berat yang sebagian besar diantaranya mengalami kejadian rakhitis. Hal ini terjadi sebab tipisnya jaringan adiposa anak-anak gizi buruk. Jaringan adiposa berfungsi sebagai tempat penyimpanan 25-hidroksivitamin D [25 (OH) D], yaitusebuah feromon yang dihasilkan di hati lewat proses hidroksilasi vitamin $\mathrm{D}_{3}$ oleh enzim kolekalsiferol 25hidroksilase. Vitamin D merupakan salah satu metabolit penting tak larut air dimana reseptor vitamin D (VDR) pada jaringan adiposit ini berperan dalam regulasi metabolisme lemak seperti lipogenesis, lipolisis, adipogenesis dan transkripsi-en adiposit. Sehingga, pemberian vitamin larut lemak seperti vitamin $\mathrm{D}$ diduga berperan dalam peningkatan berat badan anak-anak gizi buruk(Jones et al., 2018; Leblanc et al., 2012).

Sebuah studi baru-baru ini telah melaporkan bahwa cholecalciferol memiliki efek fisiologis dan biokimia terhadap tubuh. 
Cholecalciferol dapat mengurangi kelainan metabolisme dan kerusakan jaringan yang disebabkan oleh adipositas.Cholecalciferol memiliki peran langsung dalam menekan hormon paratiroid (PTH) yang mempromosikan akumulasi lemak di jaringan adiposa melalui peningkatan kalsium intraseluler(Shapses et al., 2013).Cholecalciferoldapatbertindaksebaga imediator intraseluler, menstimulasi reseptor insulin dan bertanggung jawab menjaga homeostasis kalsium. Peningkatan ukuran tubuh dan berat badanmerupakan konsekuensi kumulatif dari keberadaan cholecalciferol dan resistensi insulin (Khosravi et al., 2018).

Kurangnya kadar25-hidroksivitamin D [25 $(\mathrm{OH}) \mathrm{D}$ ] dianggap sebagai alasan dibalik adipositas yang lebih tinggi melalui regulasi hormon paratiroid (PTH) dan modulasi adipogenesis (Pereira et al., 2015).Sebagai konsekuensi dari kadar 25-hidroksivitamin D [25 (OH) D] yang rendah, peningkatan hormon paratiroidmenyebabkan masuknya kalsium ke dalam adiposit, meningkatkan lipogenesis dan menyebabkan katekolamin menginduksi lipolisis. Kondisi ini mengakibatkan akumulasi lemak yang signifikan dengan penambahan berat badan(Parikh et al., 2004). Selain itu, 1,25dihydroxyvitamin-D, bentuk aktif vitamin $\mathrm{D}$, dapat mempromosikan dan menginduksi apoptosis pada adiposit (Khosravi et al., 2018). Beberapa literatur juga menunjukkan bahwa kadar hormone paratiroid yang lebih rendah dapat menyebabkan penurunan berat badan melalui termogenesis dan lipolisis sistem saraf simpatis (Zhu et al., 2013).

Beberapa uji klinis suplementasi cholecalciferol pada komposisi tubuh dilakukan dengan menggunakan kombinasi suplementasi kalsium dan cholecalciferol. Pada studi tersebut, hasil yang didapatkan menunjukkan bahwa suplementasi cholecalciferol secara positif mempengaruhi indek massa tubuh(BMI), berat badan dan lingkar pinggang (Caan et al., 2007).

\section{Dosis Pemberian Vitamin D}

Menurut Holick et al. (2011), seseorang yang mengalami defisiensi vitamin $\mathrm{D}$ harus mengonsumsi sekitar 50.000 IU vitamin D3 per oral sekali seminggu selama 2 hingga 3 bulan, atau 3 kali seminggu selama 1 bulan. Menurut Saleem et al. 2018, administrasi pemberian dua dosis suplemen vitamin D3 sebagai terapi secara signifikan aman dalam meningkatkan berat badan dan perkembangan anak-anak gizi buruk daripada hanya mengonsumsi makanan terapeutik siap saji (RUTF). Penelitiannya menggunakan sampel 185 anak malnutrisi berat, usia rata-rata 1,9 tahun, berat $5,5 \mathrm{~kg}$ dengan rata-rata $Z$-Score $-3,9 \mathrm{SD}$ diberikan makanan terapeutik (RUTF) selama 8 minggu, 92 anak diantaranya diberikan intervensi berupa cholecalciferol (Vitamin D3) $\quad 200.000 \quad$ IU $\quad(5 \quad \mathrm{mg})$ yang diadministrasikan melalui oral maupun intravena pada minggu ke-2 dan 4. Ia menyimpulkan bahwa pemberian dosis tinggi vitamin D3 tidak mampu untuk memengaruhi proporsi anak mendapatkan $>15 \%$ dari berat badan awalnya, tetapi pemberian vitamin D3 dosis tinggi mampu meningkatkan berat badan - untuk - tinggi atau panjang $Z$-Score (selisih rata-rata yang disesuaikan) sebanyak 7\% (naik berat badan $0,26 \mathrm{~kg} \quad$ lebih $) \quad(P<0,001)$, mengurangi proporsi anak dengan keterlambatan perkembangan global $(51 \%)$ (HR, $\quad 0,49 ; P=\quad 0,002)$; mengurangi keterlambatan pengembangan motorik kasar $\quad(71 \%) \quad(\mathrm{HR}, \quad 0,29 ; P=$ 0,002); mengurangi keterlambatan perkembangan motorik halus $(41 \%)$ (HR, $0,59 ; P=.018)$, dan mengurangi perkembangan bahasa yang tertunda sebesar $\quad 43 \% \quad(\mathrm{HR}, \quad 0,57 ; P=0,036)$ dibandingkan dengan kelompok kontrol yang hanya diberikan RUTF saja. Menurut penelitian Martineau \& Jolliffe (2014), pemberian tambahan vitamin D3 juga dapat memengaruhi perkembangan otak anak. Tidak ada reaksi merugikan yang dilaporkan dalam kelompok vitamin tambahan. 


\section{Dosis Pemeliharaan Vitamin D}

Pemberian dosis pemeliharaan setelah pengoreksian defisiensi vitamin $\mathrm{D}$ pada malnutrisi berat, masih harus diteliti lebih lanjut, sebab menurut penelitianSadat-Ali et al. (2018), menyatakan bahwa pemberian dosis pemeliharaan vitamin D3 sebesar 2.000 IU tidak cukup untuk mempertahankan kadar normal metabolit aktif vitamin $\mathrm{D}\left[\left(\begin{array}{lll}25 & (\mathrm{OH}) & \mathrm{D})\end{array}\right)\right.$ dalam ambang normal yaitu di atas $30 \mathrm{ng} / \mathrm{mL}$.

\section{Toksisitas Vitamin D}

Overdosis massif vitamin D dapat menyebabkan hiperkalsemia tetapi tidak ada kesepakatan tentang ambang batas konsentrasi atau jumlah Vitamin D yang menghasilkan toksisitas sebab toksisitas vitamin $D$ sangat jarang di bawah konsentrasi serum $375 \mathrm{nmol} / \mathrm{L}$. Pada orang dewasa, asupan harian Vitamin D yang berkepanjangan hingga 10.000 IU atau konsentrasi serum $25(\mathrm{OH})$ D hingga 240 nmol/L tampaknya aman. Scientific adcisory committee nutrition (SACN) telah menerima rekomendasi Otoritas Keamanan Makanan Eropa tentang batas atas aman 1.000 unit / hari untuk bayi hingga usia 1 tahun, 2.000 unit / hari untuk anak-anak berusia 1-10 tahun dan 4.000 unit / hari untuk usia lebih dari 10 tahun (Ali et al., 2018).Pada dosis yang lebih tinggi hiperkalsemia bertanggung jawab terhadap keracunan vitamin D. Gejala awal keracunan vitamin D terdiri dari gangguan pencernaan seperti anoreksia, diare, sembelit, mual, dan muntah. Nyeri tulang, kantuk, sakit kepala terus-menerus, detak jantung tidak teratur, kehilangan nafsu makan, nyeri otot dan persendian adalah gejala lain yang kemungkinan akan muncul dalam beberapa hari atau minggu; sering buang air kecil, terutama di malam hari, haus yang berlebihan, lemah, gugup, dan gatal-gatal; batu ginjal(Alshahrani \& Aljohani, 2013).

\section{SIMPULAN}

Gizi buruk (malnutrisi) adalah keadaan dimana tubuh tidak mendapat asupan gizi cukup (terutama energi dan protein) sehingga terjadi ketidakseimbangan antara ambilan makanan dan kebutuhan gizi untuk mempertahankan kesehatan. Gejala klinis dari gizi buruk terbagi atas kwashiorkor, marasmus atau marasmik-kwashiorkor. Keadaan malnutrisi berat mungkin dikaitkan dengan adanya defisiensi vitamin D karena tipisnya jaringan adiposa dimana jaringan ini merupakan tempat penyimpanan metabolit aktif vitamin D yaitu bentuk 25-hidroksivitamin D [25 $(\mathrm{OH}) \mathrm{D}]$. Pemberian vitamin D dosis tinggi sebanyak 200.000 IU bisa sangat membantu meningkatkan berat badan untuk tinggi atau panjang z-score anak-anak malnutrisi berat. Sebab, Cholecalciferol memiliki peran langsung dalam menekan hormon paratiroid (PTH), yang mempromosikan akumulasi lemak di jaringan adiposa melalui peningkatan kalsium intraselulerSehingga peningkatan ukuran tubuh dan berat badanmerupakan konsekuensi kumulatif dari keberadaan cholecalciferol dan resistensi insulin. Selain itu, pemberian dosis vitamin $\mathrm{D}$ juga dapat mengurangi angka keterlambatan pengembangan global, motorik kasar, motorik halus dan bahasa.

\section{DAFTAR PUSTAKA}

Alshahrani, F., \& Aljohani, N. (2013). Vitamin D: Deficiency, sufficiency and toxicity. Nutrients, 5(9), 36053616.https://doi.org/10.3390/nu50936 05

Caan, B., Neuhouser, M., Aragaki, A., Lewis, CB., Jackson, R., LeBoff, MS., ... LaCroix, A. (2007). Calcium plus vitamin D supplementation and the risk of postmenopausal weight gain. Arch. Intern. Med. 167, e893-e902. https://doi.org/10.1001/archinte.167. $\underline{9.83}$

Gordon, C. M., Feldman, H. A., Williams, A. L., Kleinman, P. K., Perezrossello, J., \& Cox, J. E. (2008). Prevalence of vitamin D deficiency among healthy infants and toddlers. 
Arch Pediatr Adolesc Med. 2008;162(6):505-12. Archives of Pediatrics \& Adolescent Medicine, 162(6), 505-512. https://doi.org/10.1001/archpedi.162. 6.505.Prevalence

Herrmann, M., Farrell, C. J. L., Pusceddu, I., Fabregat-Cabello, N., \& Cavalier, E. (2017). Assessment of Vitamin D status - A changing landscape. Clinical Chemistry and Laboratory Medicine, 55(1), 3-26. https://doi.org/10.1515/cclm-20160264

Hidayat AA. (2011). Ilmu pengantar keperawatan anak. Jakarta: Salemba Medika.

Holick, M. F., Binkley, N. C., BischoffFerrari, H. A., Gordon, C. M., Hanley, D. A., Heaney, R. P., ... Weaver, C. M. (2011). Evaluation, treatment, and prevention of vitamin D deficiency: An endocrine society clinical practice guideline. Journal of Clinical Endocrinology and Metabolism, 96(7), 1911-1930. https://doi.org/10.1210/jc.2011-0385

Jones, K. D. J., Hachmeister, C. U., Khasira, M., Cox, L., Schoenmakers, I., Munyi, C., ... Berkley, J. A. (2018). Vitamin D deficiency causes rickets in an urban informal settlement in Kenya and is associated with malnutrition. Maternal and Child Nutrition, 14(1), 18.https://doi.org/10.1111/mcn.12452

Kementerian Kesehatan Republik Indonesia. (2015). InfoDATIN : Situasi Kesehatan Anak Balita di Indonesia. Kementerian Kesehatan Republik Indonesia. Retrieved Fromhttp://www.depkes.go.id/folder/ view/01/structure-publikasi-pusdatininfo-datin.html

Kementerian Kesehatan Republik Indonesia. (2015). Profil Kesehatan
Indonesia Tahun 2015. Kementerian Kesehatan Republik Indonesia. Retrieved

Fromhttp://www.depkes.go.id/resourc es/download/pusdatin/profil-

kesehatanindonesia/profil-kesehatan Indonesia-2015.pdf

Kemenkes RI. (2011). Pedoman Pelayanan Anak Gizi Buruk. Jakarta: Depkes RI.

Kementrian Kesehatan Republik Indonesia. (2019). Status Gizi Indonesia Alami Perbaikan. Kementrian Kesehatan Republik Indonesia. Retrieved From http://www.depkes.go.id/article/view/ 19013100001/status-gizi-indonesiaalami-perbaikan.html

Khosravi, Z,S., Kafeshani, M., Tavasoli, P., Zadeh, A,H., Entezari, M,H. (2018). Effect of Vitamin D supplementation on weight loss, glycemic indices, and lipid profile in obese and overweight women: A clinical trial study. Int. J. Prev. $\quad$ Med. 9:63 https://doi: 10.4103/ijpvm.IJPVM_329_15

Leblanc, E. S., Rizzo, J. H., Pedula, K. L., Ensrud, K. E., Cauley, J., Hochberg, M., \& Hillier, T. A. (2012). Associations between 25hydroxyvitamin D and weight gain in elderly women. Journal of Women's Health, 2l(10), 10661073.https://doi.org/10.1089/jwh.201 2.3506

Lee, J. Y., So, T.-Y., \& Thackray, J. (2013). A Review on Vitamin D Deficiency Treatment in Pediatric Patients. The Journal of Pediatric Pharmacology and Therapeutics, 18(4), 277-291. https://doi.org/10.5863/1551-677618.4.277

Lelijveld, N., Seal, A., Wells, J. C., Kirkby, J., Opondo, C., Chimwezi, E., ... Kerac, M. (2016). Chronic disease outcomes after severe acute malnutrition in Malawian children (ChroSAM): a cohort study. The 
Lancet Global Health, 4(9), e654e662.https://doi.org/10.1016/S2214109X(16)30133-4

Lestari, W., Margawati, A., \& Rahfiludin, M. Z. (2014). Faktor risiko stunting pada anak umur 6-24 bulan di kecamatan Penanggalan kota Subulussalam provinsi Aceh. Jurnal Gizi Indonesia: The Indonesian Journal of Nutrition, 3(1), 37-45. https://doi.org/10.14710/jgi.3.1.126134

Martineau, A., \& Jolliffe, D. (2014). "Vitamin D and Human Health: from the Gamete to the Grave": Report on a meeting held at Queen Mary University of London, 23rd-25th April 2014. Nutrients, 6(7), 27592919.https://doi.org/10.3390/nu60727 59

Parikh, S. J., Edelman, M., Uwaifo, G. I., Freedman, R. J., Semega-Janneh, M., Reynolds, J., \& Yanovski, J. A. (2004). The relationship between obesity and serum 1,25-dihydroxy vitamin D concentrations in healthy adults. Journal of Clinical Endocrinology and Metabolism, 89(3), 1196-1199. https://doi.org/10.1210/jc.2003031398

Pereira-Santos, M., Costa, P,R., Assis, A,M., Santos, C,A., Santos, D,B. (2015). Obesity and vitamin D deficiency: A systematic review and meta-analysis. Obes. Rev. 16 :e341e349https://doi.org/10.1111/obr.1223 $\underline{9}$

Raghuramulu, N., \& Reddy, V. (1980). Serum 25-hydroxy-vitamin D levels in malnourished children with rickets. Archives of Disease in Childhood, 55(4), 285-287. https://doi.org/10.1136/adc.55.4.285

Saboya M, Khara T, Irena A. (2011). Harmonization Training Package
Version 2 Module 13: Management of Severe Acute Malnutrition. Oxford. Retrieved from http: //www.ennonline.net/ourwork/capacit ydevelopment/htpversion2

Sadat-Ali, M., Al-Anii, F. M., Al-Turki, H. A., AlBadran, A. A., \& AlShammari, S. M. (2018). Maintenance Dose of Vitamin D: How Much Is Enough? Journal of Bone Metabolism, 25(3), 161.https://doi.org/10.11005/jbm.201 8.25.3.161

Saleem, J., Zakar, R., Zakar, M. Z., Belay, M., Rowe, M., Timms, P. M., ... Martineau, A. R. (2018). High-dose Vitamin D 3 in the treatment of severe acute malnutrition: A multicenter double-blind randomized controlled trial. American Journal of Clinical Nutrition, 107(5), 725-733. https://doi.org/10.1093/ajcn/nqy027

Shapses, S. A., Sukumar, D., Schneider, S. H., Schlussel, Y., Sherrell, R. M., Field, M. P., \& Ambia-Sobhan, H. (2013). Vitamin D supplementation and calcium absorption during caloric restriction: A randomized doubleblind trial1-3. American Journal of Clinical Nutrition, 97(3), 637645.https://doi.org/10.3945/ajen.112. 044909

Supariasa IDN. (2012). Pendidikan dan konsultasi gizi. Jakarta: EGC.

United Nations. (2013). The millennium development goals report 2013. Retrieved From https://www.un.org/millenniumgoals/ pdf/report-2013/mdg-report-2013english.pdf

World Health Organization. (2013). Guideline: update of management of severe acute malnutrition in infants and children in Geneva, Switzerland.World Health Organization. Retrieved Fromhttps://apps.who.int/iris/bitstrea 
$\underline{\mathrm{m} / \mathrm{handle} / 10665 / 95584 / 97892415063}$

28_eng.pdf?ua $=1$

Zhu, W., Cai, D., Wang, Y., Lin, N., Hu, Q., Qi, Y., ... Amarasekara, S. (2013). Calcium plus vitamin D3 supplementation facilitated Fat loss in overweight and obese college students with very-low calcium consumption: a randomized controlled trial. Nutrition Journal, 12(1), $1-8$. https://doi.org/10.1186/1475-2891$12-8$ 
Jurnal Penelitian Perawat Profesional, Volume 1 No 1 Hal 61 - 70, November 2019 Global Health Science Group 